\title{
INTER-REGIONALISM REVISITED: THEORY AND POLITICAL REALITY OF EUROPE-ASIA RELATIONS ${ }^{1}$
}

\author{
Jörn Dosch
}

\begin{abstract}
While some authors have suggested that theoretical contributions to the study of interregionalism mostly lack sufficient empirical proof, this article shows that there is ample evidence to support key prepositions of all three schools of thought in the debate (neorealism, liberal institutionalism and social constructivism). Existing cooperation mechanisms in Europe-Asia relations are not just 'talking shops' but fulfil important functions in the international system. However, the main shortcoming of the inter-regionalism discourse todate is its analytical one-eye blindness: the political realities of inter-regional cooperation are reduced to interactions between the two region's foreign policy elites and have a strong focus on dialogue fora such as ASEM. The article explains that the promotion of good regional governance, economic integration and peace-building through development assistance (ODA) is the more effective part of the European Union's (EU) foreign relations with East Asia as compared to high-level diplomacy in the framework of ASEM or the official EU-ASEAN dialogue.
\end{abstract}

Keywords: Europe-Asia relations, inter-regionalism, European Union, ASEAN, East Asia, regional governance, economic integration, peace-building

\section{INTRODUCTION}

As elsewhere in the world after the fall of the Berlin Wall and the end of the Cold War, academic and public discussion in Europe focused on whether the so-called new world order would be dominated by the United States or would develop into a multipolar system with the United States, East Asia and the European Union (EU) as its principal centres. In 1992, when ASEAN announced the gradual implementation of a Southeast Asian Free Trade Area (AFTA) and in 1993 when the APEC countries' heads of state met for the first time in Seattle, European newspapers published scenarios presenting AFTA and APEC as emerging trading blocs and direct competitors of the European Common Market. Although it soon became clear that economic co-operation in the Asia-Pacific will not lead in the foreseeable future to a level of integration comparable to Europe's, many in Bonn, Paris, Rome and other capitals worried that a 'Pacific Century' could leave Europe as the odd person out in the new international order. Special attention was given to the role of the United States. It was believed that Washington would shift its main foreign policy focus from transatlantic to transpacific relations (although the United States was a Pacific power long before it became an Atlantic one). Concern was caused by trade figures showing that in 1995, for example, 66 percent of total US trade was carried out within the Asia-Pacific area (including Canada). At the same time, of the ten biggest US trading partners five were Asian economies (Japan, 
China, Taiwan, South Korea and Singapore, in this order) but only three were European (Germany, the United Kingdom and France).

As a result of this perception, both the EU and individual member states have strengthened their relations with East Asian states. In the international relations literature the term inter-regionalism has been coined for such a process that links up entire geographical regions or even continents in an attempt to increase the level of institutionalization in relations between them. The inter-regionalism discourse emerged and differentiated itself from regional integration theory when scholars started to understand that regions were becoming actors in their own right. Regions such as Western Europe and Southeast Asia exercised this status by developing their own external relations. Most authors distinguish three types of interregional patterns: relations between regional groupings and organizations, such as the EU and ASEAN, are called bilateral inter-regionalism. Trans-regional arrangements are more heterogeneous and membership is more diffuse than in traditional group-to-group dialogues; membership of trans-regional processes is comprised of individual countries that may or may not be part of other regional groups. The best studied example of trans-regionalism is the Asia-Europe Meeting (ASEM). Hybrid inter-regionalism usually refers to relations between regional groupings and single states, for example relations between the EU and China. ${ }^{2}$ Most studies have focused on the reasons for the emergence, development and maintenance of interregional dialogues and relations, including neo-realist, institutional and social constructivist arguments. ${ }^{3}$ Jürgen Rüland has described seven functions of inter-regionalism as discussed by the various schools of thought: balancing and bandwagoning, institution-building, rationalizing, agenda-setting and controlling, identitybuilding, stabilizing and development. ${ }^{4}$

In this article I will first look at the main arguments of the academic discourse on inter-regionalism before evaluating the cases of EU-ASEAN and ASEM as the two pillars of inter-regional relations between Europe and Asia. In second part the empirical findings will be discussed from the angles of neo-realism, institutionalism and social constructivism. Contrary to the assessment of Hänggi, Roloff and Rüland ${ }^{5}$ that theoretical contributions to the study of inter-regionalism mostly lack sufficient empirical evidence, this article shows that there is sufficient evidence to support key prepositions of all three schools of thought in the debate. A note on terms: The European Community (EC) transformed itself into the European Union (EU) in 1992. In the following any mentioning to the EC refers to the pre-1992 period. In most publications and documents the abbreviation EC is also used for the European Commission, the executive branch of the European Union. To avoid confusion, European Commission or just Commission are always spelled out in this article.

\section{THE INTER-REGIONALISM DISCOURSE}

In addition to a broad range of internal dynamics, processes of regional cooperation and more specifically regional identity building are almost always also influenced by the "actions and attitudes of states external to the system" "6 as well as international structures. In sum, these socalled external federators: ${ }^{7}$

are actors or situations which provoke regionalist reactions and/or pursuits of cultural or situational identities via assistance, pressure, or simply by their mere existence. The Soviet Union and the USA contributed in a substantial way to the formation of an integrated Europe, and Washington 
was a principal external federator in nearly all efforts of Latin American integration.

External stimuli do not have to be of a direct and explicit nature but can also include distant events and developments that at first glance do not seem to bear much importance for other regions. For example, "many [in Asia] believed that the euro as a symbol of EU's success story of integration would have a stimulating effect on their own regional cooperation." ${ }^{\prime 8}$ Inter-regionalism plays an important role as an external federator because it " explicitly sets one region in a dialogue (or potentially a conflict) with an 'other'... As one bounded entity comes into contact with another, a pool of recognition and knowledge comes into being at the level where the interaction occurs ...". 9

The phenomenon of inter-regionalism - the process through which patterns of relations between geographical regions are institutionalized ${ }^{10}-$ is often marked by certain common characteristics such as 'soft' institutional structures and processes, which in turn are characterized by informality, consensus orientation, and pragmatism. A second common feature is the somewhat controlled shift of contentious issues from the official level (track one) to the non-governmental level (track two) in order to discuss these issues noncontroversially and to avoid a political stalemate among the parties. Taking into consideration all existing inter-regional arrangements, which also exist between Asia and Latin America, Europe and Africa etc., it becomes obvious that they differ with regard to membership, the degree of institutionalization, and the policy areas covered by the arrangement.

Inter-regionalism emerges as a response to specific configurations and the increasing complexity of the international system. Hence, in light of a perceived erosion process of nation-states' steering mechanisms in the era of globalization, inter-regionalism just as regionalism appears to offer state actors new action corridors and a tool to explore and to regain (lost) political steering competencies. According to Maull, this allows states to pursue the following three objectives: (1) accumulation of wealth through intensified trade and investment relations as well as through deepened forms of transnational division of labor; (2) cooperative management of general problems of interdependence (rule-setting, regime creation, crisis prevention) and of specific conflicts of interdependence (tariff- and nontariff barriers, dumping); and (3) strengthening of the major industrialized region's bargaining power with regard to the definition of the rules of the international economic system. ${ }^{11}$ Consequently, inter-regionalism serves as a political vehicle for the deepening of interdependence, the mutual increase of material and nonmaterial resources, and the resolution of conflicts through the use of accompanying measures and additional cooperation between governmental and non-governmental actors. It performs certain balancing functions, and contributes to multilateral institution and identity building in international relations. ${ }^{12}$ All these objectives and functions can be identified in relations between Europe and East Asia, particularly with regard to EU-ASEAN relations and the Asia-Europe Meeting (ASEM).

\section{RELATIONS BETWEEN THE EU AND ASEAN}

When the foreign ministers of Indonesia, Malaysia, the Philippines, Singapore and Thailand gave birth to ASEAN in August 1967, one main objective was "to maintain close and beneficial co-operation with existing international and regional organizations with similar aims and purposes", as stated in the Bangkok Declaration, the organisation's founding document. Five years later, in April 1972, ASEAN launched a Special Co-ordination Committee (SCANN) to conduct an institutionalised dialogue with the European Community. 
This way, the European Community became ASEAN's first "Dialogue Partner". A few months later, this initiative led to the establishment of the ASEAN-Brussels Committee (ABC), comprising ASEAN ambassadors accredited to the EC to act as its outpost in Europe. The ABC-which was the first ASEAN Committee in a third country - stands for the beginning of formalized ASEAN-EC/EU relations. In 1974, a Joint ASEAN-EC Study Group was established as an alternative to the commercial co-operation agreements that had been negotiated bilaterally between the EC and the Commonwealth countries. And in November 1979, the first ASEAN-EC Ministerial Meeting (AEMM) took place.

The signing of the ASEAN-EC Cooperation Agreement in Kuala Lumpur in 1980, marked an important step in the cooperation process between the two organisations. It was the first international treaty that the European Community signed with any other regional organisation. Of particular importance was the statement in the agreement that "such cooperation will be between equal partners", without disclaiming that it will "take into account the level of development of the member countries of ASEAN and the emergence of ASEAN as a viable and cohesive grouping, which has contributed to the stability and peace in Southeast Asia." This new effort was particularly motivated by the urgency of working jointly at the international level to deal with major economic issues. The Agreement extended the Most Favoured Nation (MFN) treatment to the contracting parties. It also opened up an exclusive channel for the exchange of information and requests that paved the way for EC assistance in several development projects. It opened up a second track of cooperation which specifically covered the EC and the signatories of the Cooperation Agreement. Under the treaty, objectives for commercial, economic and technical cooperation were established and a Joint Cooperation Committee (JCC) was formed as a mechanism to monitor ASEAN-EC cooperation. ${ }^{13}$ Protocols for the accession of Laos and Cambodia to the Agreement were signed in July 2000 but the EU indicated that it cannot agree to negotiate an extension of this agreement to Myanmar as long as the situation as regards democracy and human rights in that country does not improve significantly. Myanmar may participate in EC-ASEAN cooperation actions provided they are in line with the EU Common Position on restrictive measures against this country. ${ }^{14}$

Since the early 1990s, both sides have been trying to reach a new cooperation treaty. So far, however, different opinions concerning questions of if, in what form and to what extent aspects of human rights, sustainable development and good governance should be stressed in the new treaty as well as divergent views on Myanmar have hindered the successful formulation of a draft acceptable to both sides. In recognition that, while renegotiation of the 1980 Agreement was not feasible, EC-ASEAN relations needed to be revitalised, in 2003 the European Commission issued a new strategic document entitled "A New Partnership with Southeast Asia" which identified the following key priorities:

- Supporting regional stability and the fight against terrorism;

- Human rights, democratic principles, and good governance;

- Mainstreaming justice and home affairs issues;

- Injecting a new dynamism into regional trade and investment relations;

- Continuing to support the development of less prosperous countries;

- Intensifying dialogue and cooperation in specific policy areas.

The Nuremberg Declaration on an EU-ASEAN Enhanced Partnership ${ }^{15}$ has further specified the cooperation agenda in five broad areas: political and security cooperation; economic cooperation; cooperation in the field of energy security and climate 
change/environment; socio-cultural cooperation and development cooperation. This agenda has been further extended and deepened by the Bandar Seri Begawan Plan of Action to Strengthen the ASEAN-EU Enhanced Partnership (2013-2017) which adds or strengthens “ gender equality, well-being of women, children, the elderly and persons with disabilities and migrant workers", "building together disaster-resilient communities" and "cooperation in Science and Technology (S\&T)" as central action points. ${ }^{16}$ The Nuremberg Declaration and the Bandar Seri Begawan Plan of Action express the signatories' interest in the promotion of a long list of liberal values, including to but limited to the universal values of justice, democracy, human rights, good governance, anti-corruption, and the rule of law, while the PoA includes a particular commitment to the strengthening of cooperation on human rights and in the fight against corruption. A first-ever EU-ASEAN Summit took place on 22 November 2007 in Singapore to celebrate 30 years of formal relations between the EU and ASEAN and to mark the beginning of a higher level of cooperation under the Nuremberg Declaration.

It is the academic preoccupation with official diplomacy in EU-ASEAN relations that has resulted in a wide-spread international perception that EU-ASEAN interaction had not achieved much beyond political rhetoric. This assessment is correct as far as it is indeed limited to official inter-governmental relations. Robles' finding is still valid to a great extent: "the ASEAN-EU dialogue... failed to create an enduring relationship that provided opportunities for and imposed constraints on action on the part of ASEAN and the EU."17 However, this picture markedly changes if one also looks at development cooperation. In many ways, the promotion of regional integration and "good regional governance" through Official Development Assistance (ODA) is the more significant and also more effective part of the EU's foreign relations with ASEAN. Yet, the conduct of development cooperation tends not to appear on the radar screen of most analysts. Even Rudolfo Severino's otherwise very insightful account Southeast Asia in Search of an ASEAN Community only briefly touches upon this aspect. ASEAN-EU development cooperation, writes the former ASEAN Secretary General, "is meant to equip ASEAN - ASEAN Secretariat and its member states with knowledge, insights and expertise in different elements of regional economic integration." 18 Severino mentions details of several EU- funded cooperation projects but does not elaborate on their impact on Southeast Asian regionalism and integration. The same analytical neglect of development cooperation that characterizes publications on EU-ASEAN relations does also applies to studies of ASEAN's relations with the US ${ }^{19}$, Japan ${ }^{20}$ and Australia, all three providers of large ODA funds to ASEAN. In reality, the impact of foreign donors on Southeast Asian regionalism has been significant. An independent evaluation of the European Commission's cooperation programme with ASEAN between 1996 and 2007 found that:

- EC assistance to ASEAN contributed significantly to progress made in regional economic integration and has helped to foster closer EC-ASEAN trade relations;

- the EC (and Europe more generally) is regarded by ASEAN and national government officials as an important source of concrete experiences which may be studied to better design and implement ASEAN integration; and

- EU cooperation in the field of energy and biodiversity conservation successfully introduced European best practices of sustainable economic development to the ASEAN region ${ }^{21}$ 
Table 1: Major ASEAN Projects Funded by the European Commission, 1991-2009

\begin{tabular}{|c|c|c|c|}
\hline Project & $\begin{array}{l}\text { Start - } \\
\text { End }\end{array}$ & $\begin{array}{l}\text { EC } \\
\text { Contribution } \\
\text { (in million } € \text { ) }\end{array}$ & Objectives \\
\hline $\begin{array}{l}\text { ASEAN-EU } \\
\text { University } \\
\text { Network } \\
\text { Programme }\end{array}$ & $2002-2006$ & 7 & $\begin{array}{l}\text { Facilitate EU-ASEAN cooperation in } \\
\text { higher education / Strengthen capacity } \\
\text { of universities in SE Asia }\end{array}$ \\
\hline $\begin{array}{l}\text { EU-ASEAN } \\
\text { COGEN } \\
\text { Programme } \\
\text { (COGEN I, II, and } \\
\text { III) }\end{array}$ & $1991-2004$ & 14.4 & $\begin{array}{l}\text { Accelerate through pilot projects } \\
\text { implementation of } \\
\text { cogeneration technologies } \\
\text { industrial sectors in ASEAN region }\end{array}$ \\
\hline $\begin{array}{l}\text { EC-ASEAN } \\
\text { Energy Facility }\end{array}$ & $\begin{array}{l}\text { March } \\
2002- \\
\text { February } \\
2007 \\
\end{array}$ & 21.5 & $\begin{array}{l}\text { Stimulate regional energy projects and } \\
\text { initiatives proposed by energy industry } \\
\text { from ASEAN and EU }\end{array}$ \\
\hline $\begin{array}{l}\text { ASEAN Regional } \\
\text { Centre for } \\
\text { Biodiversity } \\
\text { Conservation }\end{array}$ & 1999-2004 & 9.4 & $\begin{array}{l}\text { Promote establishment of regional } \\
\text { network between EU and Asia and } \\
\text { within ASEAN }\end{array}$ \\
\hline $\begin{array}{l}\text { ASEAN Centre } \\
\text { for Biodiversity }\end{array}$ & $2006-2009$ & 6 & $\begin{array}{l}\text { Encourage and enable ASEAN Member } \\
\text { States to achieve a significant reduction } \\
\text { of biodiversity loss by } 2010\end{array}$ \\
\hline $\begin{array}{l}\text { ASEAN } \\
\text { Programme for } \\
\text { Regional } \\
\text { Integration } \\
\text { Support (APRIS } \\
\text { 1) }\end{array}$ & $\begin{array}{l}\text { February } \\
2003- \\
\text { September } \\
2006\end{array}$ & 4.5 & $\begin{array}{l}\text { Strengthen EU-ASEAN relations as a } \\
\text { whole and complement ongoing EC- } \\
\text { ASEAN dialogue / Institution building } \\
\text { at ASEAN Secretariat }\end{array}$ \\
\hline APRIS 2 & $\begin{array}{l}\text { November } \\
2006- \\
\text { November } \\
2009\end{array}$ & 6.2 & $\begin{array}{l}\text { Same; subsumes Standards and support } \\
\text { to regional integration under TREATI } \\
\text { and READI as well as activities to raise } \\
\text { EU visibility. Components: } \\
\text { - Standards and SPS } \\
\text { - Customs and Trade Facilitation } \\
\text { - Investment } \\
\text { - Capacity building } \\
\text { O Improved legal capacity at } \\
\text { ASEAN Secretariat } \\
\text { Training of ASEAN } \\
\text { Secretariat and ASEAN } \\
\text { Member Country officials on } \\
\text { Working Groups } \\
\text { Committees }\end{array}$ \\
\hline EC-ASEAN & 1993-2000 & 9 & Enhance investment and trade by \\
\hline
\end{tabular}




\begin{tabular}{|c|c|c|c|}
\hline $\begin{array}{l}\text { Intellectual } \\
\text { Property Rights } \\
\text { Programme } \\
\text { (ECAP I and } \\
\text { ECAP II) }\end{array}$ & $\begin{array}{l}\text { (ECAP I) } \\
2002-2007 \\
\text { (ECAP II) }\end{array}$ & & $\begin{array}{l}\text { contributing to upgrade the ASEAN IPR } \\
\text { systems in line with international } \\
\text { standards and practices }\end{array}$ \\
\hline $\begin{array}{l}\text { EC-ASEAN } \\
\text { Regional } \\
\text { Economic } \\
\text { Cooperation } \\
\text { Programme on } \\
\text { Standards, } \\
\text { Quality, and } \\
\text { Conformity } \\
\text { Assessment }\end{array}$ & $\begin{array}{l}\text { February } \\
1998- \\
\text { December } \\
2005\end{array}$ & 10.7 & $\begin{array}{l}\text { Achieve further economic cooperation } \\
\text { by adoption by ASEAN of } \\
\text { internationally compatible technical } \\
\text { regulations and standards; conformity } \\
\text { assessment procedures, quality } \\
\text { structures and practices. }\end{array}$ \\
\hline $\begin{array}{l}\text { Civil Aviation } \\
\text { Programme }\end{array}$ & $2002-2006$ & 8.5 & $\begin{array}{l}\text { Enhance aviation safety and secure } \\
\text { sustainable development of the highest } \\
\text { safety standards in Asia; facilitate links } \\
\text { between European and Asian } \\
\text { companies; provide for development of } \\
\text { civil aviation industry to cope with } \\
\text { rising demand in Asia. }\end{array}$ \\
\hline
\end{tabular}

Between 1996 and 2007 the EC disbursed nearly $€ 100$ million in ODA for several major projects to promote and foster ASEAN integration, ranging from capacity building programmes at the ASEAN Secretariat to the standardization of national Intellectually Property Rights (IPR) regimes in ASEAN member states and harmonization of customs procedures throughout Southeast Asia. For the period 2008-2010, the Commission committed $€ 37$ million for the support of ASEAN Integration. In its Regional Programming for Asia Strategy Document 2007-2013, the European Commission identified "support to regional integration (through ASEAN / SAARC and ASEM)" as the first of three priority areas. ${ }^{23}$ In addition to the Commission's contributions, individual EU member states (particularly Germany, France, the UK, Denmark and Sweden) have funded development projects broadly targeted at the support for regional integration either at the ASEAN Secretariat or in ASEAN member states. According to this author's rough estimates, the total of EU member states' current ODA for ASEAN at least equals the amount of the European Commission's ODA. This means that financial support for ASEAN from EU sources alone (at the current exchange rate) amounts to an annual average of currently approximately US $\$ 33$ million or 2.4 times ASEAN's official annual budget of US\$14 million in 2011. This budget is the sum of the ASEAN member state's contributions of US\$1.4 million each.

Commission support in the 2007-2013 funding cycle is mainly directed at the implementation of the ASEAN Economic Community Blueprint, which was adopted in 2007, and outlines the vision of a stable, prosperous and highly competitive region, functioning as a single market and production base by 2015. Important crosscutting issues such as 'good economic governance', gender impact and sustainable development are also taken into account.

\section{THE ASIA EUROPE MEETING (ASEM)}


Closely connected with - but formally independent from the EU-ASEAN dialogue is the Asia-Europe Meeting (ASEM), "Europe's main multilateral channel for communication with Asia." ${ }^{24}$ Singapore was ASEM's main initiator, strongly supported by France. The first meeting was held in Bangkok in March 1996, followed by summits in London (1998), Seoul (2000), Copenhagen (2002), Hanoi (2004), Helsinki (2006), Beijing (2008), Brussels (2010), and Vientiane (2012). According to the official political statements, ASEM "aims to strengthen the relationship and increase mutual understanding between the two regions, in a spirit of mutual respect and equal partnership." ${ }^{25}$ Initially consisting of 23 members, in 2010 ASEM comprised all EU and ASEAN states, the ASEAN Secretariat and the European Commission (both participants in their own right), China, India, Japan, Mongolia, Pakistan and South Korea, 45 members in total.

Although the endeavour involves more than just EU- and ASEAN-members, the process has been dominated by these two organisations. For most of the 1990s the vaguely formulated 1994 document "Towards a New Asia Strategy" had formed the authoritative basis for the EU's strategic perception of East Asia. The paper reflected Europe's fear of becoming marginalized in a prosperous Asia-Pacific which was supposed to be the world's prime economic powerhouse by the year $2000 .^{26}$ However, the economic and political face of the region has significantly changed since the mid-1990s and so have European perceptions, strategies and policies. The founding of ASEM was the joint European-East Asian answer to the ongoing process of transpacific cooperation as materialized in APEC and other organizations. ASEM came into existence with the aim of closing or at least narrowing the institutional gap between Europe and Asia by providing the long missing 'third link' of the post-Cold War triangular world order. An early Asian position paper, which was circulated among senior officials in 1995, clearly outlined this rationale for ASEM: ${ }^{27}$

North America is linked to Europe through the rich network of TransAtlantic institutions. East and North America are linked by APEC and other pacific Basin networks. What is palpably absent is a strong highlevel Europe-Asia link. This missing link needs to be bridged. Global prosperity is more likely to be assured if the triangular relationship between North America, Europe and East Asia is strong and balanced on all three sides.

Although not explicitly stated, for both European and Asian actors the main motivation for ASEM's formation was a perceived need to balance the preeminent if not hegemonic position and role of the United States in the Asia Pacific region. And related, " ASEM also acts as a corrective against the perceived dominance that "the West" equals the United States in international relations." 28

The ASEM process consists of three main pillars: the political pillar, the economic pillar and the social, cultural, and intellectual pillar. Political dialogue is a key element. ASEM meetings at the level of Heads of State and Government, as well as among Foreign Ministers and other line ministries, provide a forum for Asian and European countries to discuss major global issues such as - in no particular order of significance - trade, terrorism, weapons of mass destruction, international migration, global environment, human rights, and the impact of globalisation.

Additionally, non-governmental actors in Europe and Asia have strengthened their relations amongst each other on the so-called 'track-two' level, confirming the main 
proposition of analysts that inter-regionalism never finds its expression solely in intergovernmental cooperation but always comprises a strong non-state orientation. Among the most important non-state cooperation mechanisms is the Asia-Europe Foundation (ASEF), a Singapore-inspired think tank that aims to boost intellectual, cultural and economic interaction between the two regions. Other achievement of fostering the cooperation among non-state actors through the ASEM process are the Trans-Eurasia Information Network (TEIN) the first large-scale research and education network connecting regional researchers in Asia and Europe. Lawmakers, businesses and civil society organizations participate in the Asia Europe People's Forum, the Asia-Europe Parliamentary Partnership and Asia-Europe Business Forum, held every two years alongside ASEM Summits. ${ }^{29}$

The most obvious rational for the existence of ASEM lies in the simple fact that the forum provides the structure for a regular policy dialogue among a highly diverse group of governments that do not necessarily share the same interests, strategies and priorities in international relations. ASEM offers its members the opportunity of carefully testing the waters for new initiatives that can later be followed up in smaller and more formalized diplomatic settings either within the context of bilateral relations or less diverse multilateral groupings. This process of agenda-setting, to use the term of the inter-regionalism literature, has become particular important for relations between the EU and China. More often than not does ASEM give both sides a first chance to discuss their respective viewpoints of emerging issues in international relations. As a European senior diplomat explains, "China is very proactive [in ASEM] on political issues and increasingly open to agendas that used to be taboo only a short while ago, including regionalism, monetary integration, and even democracy and civil society. Beijing is constantly testing new ideas. Anything goes as long as Taiwan, Tibet and Falun Gong are not mentioned." ${ }^{30}$ In a similar vein, ASEM has provided a shortcut to Asia for new EU members who have joined the EU (and therefore also ASEM) since 2004 in the same way that ASEM facilitated easy access to Europe for new Asian members of the forum. According to a high-ranking official in the Polish Ministry of Foreign Affairs, "Our EU membership [which was achieved in 2004] has given us more possibilities of cooperation with Asia, particularly in view of access to the EU's strategic partnerships with China, Japan and India and the dialogue with South Korea. Accession to ASEM became very central for us because it offered immediate and direct involvement in the EU's externals affairs with Asia." 31

So far I have presented some anecdotal evidence for the establishment and durability of ASEM but will now turn to a more systematic discussion of inter-regionalism from the perspectives of the three main schools of thought.

\section{INTERREGIONALISM: A BALANCE SHEET}

Yeo Law Hwee neatly summarises the different theoretical perspectives on inter-regionalism as follows: ${ }^{32}$

For the realists, the primary function of inter-regional dialogues or cooperation frameworks is balancing. Institutionalists on the other hand, highlight the potential of inter-regional dialogues serving as rationalisers or agenda-setters in global multilateral forums, and most importantly, their contribution to overall institution-building in an emerging multilayered system of global governance. Finally, there are also the social constructivists who essentially see inter-regional forums as identity 
builders as they claim that inter-regional dialogues can trigger and stimulate processes of intra-regional coordination and cooperation.

To what extent has inter-regionalism in relations between Europe and Asia (drawing both on bilateral inter-regionalism in the case of EU-ASEAN and the trans-regional form of ASEM) fulfilled these functions? Most observers agree that inter-regionalism has contributed to a strengthening of the 'global triad', e.g. the international order of the post-Cold War era approaches a model in which relations between (a) the United States and the European Union, (b) the United States and Asia, and (c) Asia and the European Union form the three major strands. However, does the existence of a triad imply that the actors located at the different edges of this triangle try to balance each other in order to keep the overall structure stable?

\section{THE NEO-REALIST ANGLE}

Rüland distinguishes two forms of balancing: 'power balancing' if there is a military dimension, and 'institutional balancing' if perceived disequilibria between regions are counterbalanced by inter-regional institution-building or the activation of existing interregional forums. ${ }^{33}$ There can be little doubt as to the presence of institutional balancing. As outlined above, the creation of ASEM was primarily driven by the lack of multilateral cooperation mechanisms in relations between Europe and East Asia and based on the motivation to mirror trans-Pacific institutions, such as APEC and the ASEAN Regional Forum (ARF) that had been emerging since the late 1980s and particularly in the early 1990s. More recently, institutional balancing has become particularly visible with regards to the international political economy and materialised in a growing number of preferential and free trade agreements. When the US, Australia, New Zealand, China and Japan, to name only a few states, successfully negotiated trade agreements either with ASEAN as a group or individual member states from about 2002 onwards, it seemed only a matter of time before the EU would start its own trade talks with ASEAN.

The EU is the second largest trading partner for most countries in ASEAN after the US. ASEAN exports to the EU account for about 13 percent of its total exports, while EU exports to ASEAN amount to around 4 percent of its total exports. In 2003, the EU and ASEAN launched the Trans-Regional EU ASEAN Trade Initiative (TREATI) as a framework for dialogue and regulatory co-operation between the two regions. The priority areas for co-operation under TREATI are closely linked to ASEAN's own moves towards closer economic integration: sanitary standards agriculture and fisheries, industrial product standards and technical barriers to trade. It also covers closer cooperation in investment. ${ }^{34}$ Following on from TREATI, in May 2007, negotiations on an ASEAN-EU Free Trade Agreement were launched. Only a few months later, however, the trade talks stalled and are unlikely to be resumed.

Officially, diverging views on the participation of Myanmar in a free trade agreement were cited as the main stumbling block. But the more decisive reasons lie deeper and are of a structural nature. ASEAN remains highly diverse in terms of its member states' levels of economic development, political systems and approaches to governance, security interests and not at least strategic significance in the perception of extra-regional powers. The ASEAN Charter has provided the group with an identity makeover and legal personality but overall confirmed the traditional ASEAN way of soft institutionalization and consensus-building in the process of inter-governmental cooperation. At the same time the European Commission - 
which, as the supranational authority on all trade-related matters, negotiates free trade agreements on behalf of the EU - has a one size-fits-all approach to international trade agreements that did not play well with ASEAN negotiators. Brussels insistence on a comprehensive 'new generation' FTA that includes far-reaching legally-binding provisions on, inter alia, services, intellectual property rights and governance issues clashed with ASEAN's understanding of a more limited approach that focuses on trade liberalization only like, for example, the China-ASEAN FTA. Soon, both ASEAN and the European Commission realized that bilateralism offered a more flexible and effective approach and subsequently the Commission approached several individual ASEAN members for negotiations on bilateral free trade agreements.

While it might be far-fetched to speak of institutional balancing, there is at least strong competition between the US and the EU for institutional influence on ASEAN. This is particularly visible with regard to the planned Southeast Asian Customs Union. Both the ASEAN-US Enhanced Partnership Plan of Action (2006) and several EU-ASEAN cooperation programmes such as ASEAN Programme for Regional Integration Support (APRIS; see table 1) provide technical assistance and capacity building to assist ASEAN achieving its objective. At the core of the Customs Union is the initiative to create an ASEAN Single Window (ASW) for customs clearance; e.g. the harmonization of the ten national customs regimes. On ASW alone there are between 1000 and 2000 donor-funded activities across fifty sectors. According to the already cited evaluation report on the European Commission's support to ASEAN: ${ }^{35}$

No other aspect of economic integration has attracted more donor attention than customs harmonization as it is in the natural interest of the [European Commission] and other donors to ease the access of exporters to the Southeast Asian markets and thereby strengthen trade relations. Slow and complicated customs procedures are seen as a main hurdle to trade facilitation...

However, the myriad of EU and US-funded projects on integration in the customs sector is not well coordinated. Both Brussels and Washington are eager to promote their respective institutional designs and focus on those areas that are seen as particularly crucial for trade relations - for example Certificates of Origin in the EU case and the harmonization of ASEAN and WTO data sets as far as the US is concerned. ${ }^{36}$

Unlike in the case of institutional balancing, there is no evidence for power balancing as a function of inter-regionalism in relations between Europe and Asia. There is simply no European interest in getting prominently involved in East Asia's hard security affairs (aspects of military defence) and thereby challenging the role of the United States. Striking differences between Europe's and America's involvement in the Asia-Pacific security order are obvious. Americans are, Europeans used to be major actors in the arena of East Asian security. Whereas transpacific military relations are highly institutionalized, Europe-East Asia links lack any attempt to strengthen hard security co-operation except for occasional joint maneuvers organized by Great Britain and France as part of their arms-selling activities. Contrary to the role of the US as the pre-eminent military power, balancer and broker in the Asia-Pacific, Europeans have never returned as significant military actors to the region since the end of the colonial empires in the long aftermath of the Second World War and the British decision to withdraw its troops east of the Suez in 1968. Attempts to establish military relations with East Asian states, such as the Five-Power Defence Arrangements (FPDA) of 
1971, grouping Great Britain, Malaysia, Singapore, Australia and New Zealand, have failed as military pacts. However, FPDA continues to provide a framework for joint exercises and consultations on security matters. Additionally, neither the EU as a collective actor nor most respective member states (with the partial exception of Great Britain and France) have direct hard security interests in the region other than the general aim to contribute to stability and a peaceful regional order. The fact that Asian states possess nuclear weapons or have capabilities to build them (China, North Korea, India, Pakistan) does concern the EU and European actors have articulated and demonstrated a strong strategic interest in dealing with the problems and challenges of nuclear (and conventional) armament and proliferation in a preventive way. The EU's has played an active role in the Korean Energy Development Organization (KEDO) but has not been involved in the Six Party Talks. Overall, the EU's contribution to the management of hard security in the Asia-Pacific has been small.

\section{THE INSTITUTIONALIST ANGLE}

The EU concentrates its efforts in the area of soft or non-traditional security, focusing on good governance, the rule of law and the reduction of informal institutions (such as corruption), human and civil rights, terrorism, environmental challenges and, not least, economic stability or more specifically crisis solving and prevention. Here, the institutionalist notion of rationalizing and agenda-setting and comes into focus. It has become almost a routine matter for key ASEM members to put their main rallying points in international cooperation on the forum's agenda and to re-emphasis them in Declarations and Chairman's statements. That way the ASEM process can indeed be described as a framework which allows members to garner support for initiatives among like-minded states in non-traditional policy arenas and set the agenda in preparation for deeper institutionalized and/or global multilateral settings, such as UN conferences. For example, the 2008 ASEM summit concluded with the Beijing Declaration on Sustainable Development which stresses the mutually reinforcing nature of economic development, social progress and environmental protection, the centrality of the Millennium Development Goals (MDG) and especially the importance of climate change, energy security and social cohesion in achieving sustainable development. This is a very accurate summary of one the EU's most important strategic focal points, a policy field where the EU has established strong global leadership and also been most successful concerning development cooperation with Southeast Asia. At the same time the Declaration expresses the ASEM members' willingness to "to strengthen cooperation in a mutually beneficial manner and work towards win-win solutions so as to make positive contribution to sustainable development.", 'Win-win' is the Chinese government's favourite term to describe the purpose of international cooperation and shorthand for the claim that Beijing's foreign policy and foreign economic policy actions are by default also beneficial to its partners.

\section{THE SOCIAL CONSTRUCTIVIST ANGLE}

ASEM's function as an identity-builder is first and foremost related to the promotion of norms in the international system. Norms are collective expectations about appropriate behavior. ${ }^{38}$ In this sense, they are guidelines for behaviour of actions and they are generally abided by the members of society. Norms "are not behaviour itself but what people think behaviour ought to be." 39 Two forms of norms can be distinguished: constitutive and regulative. With regard to the international system, constitutive norms 'create' actors (sovereign states, international organizations) and contribute to the formation of their identity, while regulative norms define forms of behaviour in certain circumstances. ${ }^{40}$ In the 
case of the European Union, constitutive and regulative norms are closely intertwined. The very norms that form the normative pillars of the EU and indeed the European integration process define the endogenous and exogenous perception of how the EU should act in its external relations. For example, the Lisbon Treaty (in force since 1 December 2009) states that in international affairs the EU would be guided by - and would seek to - promote the values on which the Union is founded, including democracy, human rights, fundamental freedoms and the rule of law (Article III-193(1), Article I-2 and I-3).

The EU is widely considered - by itself and others - a distinctly "different" type of international actor. ${ }^{41}$ To this end the EU has been labelled a "civilian power" (the idea of pursuing the domestication or 'normalisation' of international relations by tackling international problems within the sphere of contractual politics) ${ }^{42}$; a soft power (forms of foreign policy influence which rely on cooptation, multilateral cooperation, international institution-building, integration and the power of attraction) ${ }^{43}$; and a normative power (a foreign policy actor intent on shaping, instilling, diffusing - and thus "normalizing" - rules and values in international affairs through non-coercive means.

No-where else is identity-building more visible than in the area of human rights. After many years of hard diplomatic lobbying, in 2000 the EU finally succeeded in including human rights on the inter-regional agenda. The Chairman's Statement of the Third AsiaEurope Meeting, which took place in Seoul in October 2000, stressed that "leaders committed themselves to promote and protect all human rights, including the right to development, and fundamental freedoms, bearing in mind their universal, indivisible and independent character as expressed at the World Conference on Human Rights in Vienna." ${ }^{44}$ Conflicting views of the concept of human and civil rights had been the most serious intervening variable in Europe-East Asia relations since 1991 when the EU decided to make human rights clauses compulsory elements of its international treaties. The inclusion of formally tabooed core issues such as human rights, rule of law and good governance on the Asia-Europe agenda represented a new quality in intraregional relations. The new commitments made in 2000 in the fields of good governance, human rights and the rule of law are significant and have steered the ASEM process ever since. It has not been possible to back away from these commitments once they had been agreed as Reiterer correctly predicted shortly after the Seoul summit. ${ }^{45}$ In other words, inter-regionalism has made an important contribution to the shaping of a collective European identity through the EU's promotion of human rights norms and liberal values in relations with East Asia.

Since 2004, when the EU and ASEAN clashed over the participation of Myanmar in ASEM - a dispute that threatened the future of ASEM on the eve of the Hanoi Summit and eventually ended in a compromise - the human rights dialogue between European and Asian actors has been constructive. And even in the case of Myanmar significant process was made insofar as the EU's agreement to allow Myanmar to participate in the ASEM summit in Helsinki (2006) gave way to human rights questions and therefore the Myanmar issue at the official level. ${ }^{46}$ At any rate, Myanmar is no longer a constraining factor in Europe-Asia relations given the country's successful opening-up and political reform process. In her detailed analysis of the European-Asian human rights discourse, Manea explains the role of inter-regionalism as an external federator, as defined at the beginning of this article, on ASEAN's approach to human rights: ${ }^{47}$

$[\mathrm{H}]$ ow ASEAN deals with human rights issues in its interregional relations with the European Union also has an impact on the intraregional dynamics 
of human rights policy and is an intrinsic part of the ongoing process of regional identity building in ASEAN. ASEAN has embarked on a gradual process of rethinking its norms of regional conduct to become more accommodating to human rights norms and policies. It has also acquired a more favorable position towards the establishment of a regional normative and institutional framework for the promotion and protection of human rights.

This development is most strongly evidenced by the ASEAN Human Rights Declaration of 2012. The increasing willingness of Asian ASEM members, not just ASEAN but also China, to engage in an inter-regional human rights dialogue in turn has paved the way for the inclusion of human rights-related projects in the EU's bilateral development programme with Southeast Asian nations and China. Examples include the relocation of the Hmong in Laos, the situation of ethnic minorities in Vietnam (especially in the Central Highlands), the death penalty and extra-judicial killings in the Philippines and the promoting of the transition to an open society based on good governance, rule of law, and respect for human rights in China. Not all projects have been successful but the independent evaluation reports on the respective cooperation programmes (all available from the EuropeAid website) demonstrate that the EU is not a paper tiger on human rights as often charged.

\section{CONCLUSION}

It was not the purpose of this article to celebrate inter-regionalism as an efficient and effective contribution to international order-building and management and play to the tune of the official political rhetoric. However, I have tried to show that the existing cooperation mechanisms in Europe-Asia relations are not just 'talking shops' but fulfil important functions in the international system that can be analysed in a meaningful way based on neorealist, institiutionalist and social constructivist approaches. These functions are, first, balancing, second, rationalising or agenda-setting and institution-building in an emerging multilayered system of global governance and, third, identity building in the process of intraregional policy coordination and cooperation. While academic contributions to the study of Europe-Asia relations have often been accused of presenting mainly narrative-descriptive accounts, a deeper look reveals that the inter-regionalism discourse offers a fertile ground for advancement of International Relations theory. The main shortcoming of the existing mainstream in the inter-regionalism debate is its analytical one-eye blindness: the political realities of cooperation in Europe-Asia relations are reduced to interactions between the two region's foreign policy elites and a strong focus on dialogue fora such as ASEM. As discussed above, the conduct of development cooperation tends not to appear on the radar screen of analysts. In many ways, the promotion of good regional governance, economic integration and peace-building through ODA is the more interesting and also more effective part of the EU's foreign relations with East Asia, particularly ASEAN, than high-level diplomacy in the framework of ASEM or the official EU-ASEAN dialogue. It is mainly within the context of development cooperation in the broadest sense, with a strong emphasis on technical assistance, that meaningful normative change takes place in intra-regionalism relations and the stage is set for the management of relations between Europe and Asia in multiple policy areas. 


\section{NOTES}

${ }^{1}$ Research for this article was made possible by a grant from The Association of South East Asian Studies in the UK (ASEASUK) which is gratefully acknowledged.

${ }^{2}$ Charalambos Tsardanidis, "Inter-regionalism. A comparative analysis of ASEM and FEALAC," in Jörn Dosch and Olaf Jacob (eds.), Asia and Latin America, Political, Economic and Multilateral Relations, London: Routledge, 2010, pp. 218-220.

${ }^{3}$ Gracia Abad, "Non-triadic interregionalism: the case of FEALAC," in Dosch and Jacob (eds.), Asia and Latin America, pp. 206-217.

${ }^{4}$ Jürgen Rüland, 'The EU as an Inter-Regional Actor: The Asia-Europe Meeting," in Suthiphand Chirathivat et al. (eds.), Asia-Europe on the Eve of the 21st Century, Singapore: Institute of Southeast Asian Studies (ISEAS), 2002, pp. 43-56.

5 Jürgen Rüland et al., "Interregionalism: A New Phenomenon in International Relations," in Jürgen Rüland et al. (eds.), Interregionalism and International Relations, London: Routledge, 2006, p. 7.

${ }^{6}$ Julie Gilson and Yeo Lay Hwee, "Collective Identity-Building through Trans-Regionalism: ASEM and East Asian Regional Identity," in Wim Stokhof et al. (eds.), The Eurasian Space: Far More Than Two Continents, Singapore: ISEAS, 2004, p. 28.

${ }^{7}$ Manfred Mols, "Is There an Asianisation of Asia? The New Millennium in Asia and the Identity Debate," Panorama: Insights into Southeast Asia and European Affairs, Vol. 6, No. 1, 2004, p. 61.

${ }^{8}$ Minqi Xu, "The Euro and East Asian Monetary Co-operation," in Stokhof et al. (eds.), The Eurasian Space, p. 119.

${ }^{9}$ Gilson and Yeo, "Collective Identity-Building," pp. 27-28.

${ }^{10}$ Claudia Sanchez Bajo, "The European Union and MERCOSUR: A Case of Inter-Regionalism," Third World Quarterly, Vol. 20, No. 5, 1999, p. 927.

${ }^{11}$ Hanns W. Maull, "Europa und Ostasien: Eine neue Dimension des Inter-Regionalismus?" [Europe and East Asia: A New Dimension of Inter-Regionalism?], in K. Schubert and G. Müller-BrandeckBocquet (eds.), Die Europäische Union als Akteur der Weltpolitik [The European Union as an Actor in World Politics], Opladen: Westdeutscher Verlag, 2000, p. 149.

12 Rüland, "Interregionalism"; Mathew Doidge, "Joined at the Hip: Regionalism and Interregionalism," Journal of European Integration, Vol. 29, No. 2, 2007, pp. 229-48; Alfredo C. Robles, The Asia-Europe Meeting - The Theory and Practice of Interregionalism, London: Routledge, 2008; Jürgen Rüland et al. (eds.), Asian European Relations. Building Blocks for Global Governance?, London: Routledge, 2008.

${ }^{13}$ Yeo Lay Hwee, "The Inter-Regional Dimension of EU-Asia Relations: EU-ASEAN and the AsiaEurope Meeting (ASEM) Process,” European Studies, Vol. 25, 2007, pp. 173-191, p. 178.

${ }^{14}$ European Union, "Council Common Position 2009/615/CFSP, Official Journal of the European Union 14.8.2009," lex.europa.eu/LexUriServ/LexUriServ.do?uri=OJ:L:2009:210:0038:0069:EN:PDF>

$<$ http://eur-

${ }^{15}$ European Union, "Nuremberg Declaration on an EU-ASEAN Enhanced Partnership, 2007," $<$ http://www.europa-eu-un.org/articles/en/article_6866_en.htm>

${ }^{16}$ Council of the European Union, "Bandar Seri Begawan Plan of Action to Strengthen the ASEANEU Enhanced Partnership (2013-2017)," $<$ http://www.consilium.europa.eu/uedocs/cms_Data/docs/pressdata/EN/foraff/129884.pdf>

${ }^{17}$ Alfredo C. Robles, The Political Economy of Interregional Relations: ASEAN and the EU, Aldershot: Ashgate Publishing, 2004.

${ }^{18}$ Rudolfo Severino, Southeast Asia in Search of an ASEAN Community: Insights from the former ASEAN Secretary-General. Singapore: ISEAS, 2006, p. 334.

${ }^{19}$ Evelyn Goh and Sheldon W. Simon (eds.), China, the United States, and Southeast Asia: Contending Perspectives on Politics, Security, and Economics, London: Routledge, 2008.

20 , Evolution of ASEAN-Japan Relations, Singapore: ISEAS, 2005.

${ }^{21}$ European Commission, "Evaluation of EC Co-operation with ASEAN - ref. 1262, Vol. 1, p. vi," <http://ec.europa.eu/europeaid/how/evaluation/evaluation_reports/reports/2009/1262_vol1_en.pdf> 
${ }^{22}$ Ibid., p. 5.

${ }^{23}$ European Commission, "Regional Programming for Asia, Strategy Document 2007-2013," $<$ http://eeas.europa.eu/asia/rsp/07_13_en.pdf>

${ }^{24}$ Ibid., p. 10.

${ }^{25}$ See <http://ec.europa.eu/external_relations/asem/intro/index.htm>

${ }^{26}$ European Union, "Towards a New Asia Strategy' COM(94) 314 final, Brussels, 13.07.94," $<$ http://www.madrid.es/UnidadWeb/Contenidos/EspecialInformativo/RelacInternac/InversionAsia/Fi cheros/TowardsNewAsiaStrategy.pdf>

${ }^{27}$ Quoted in Andreas H. Pareira, ASEM (Asia-Europe Meeting): Bestandsaufnahme, Möglichkeiten und Grenzen einer Interregionalen Kooperation [ASEM (Asia-Europe Meeting): Stock-Taking, Possibilities, and Limits of Interregional Cooperation], Frankfurt am Main: Peter Lang, 2003, p. 7.

${ }^{28}$ Michael Reiterer, "ASEM: Value-Added to International Relations and to the Asia-Europe Relationship," in Stokhof et al. (eds.), The Eurasian Space, p. 14.

${ }^{29}$ See $<$ http://ec.europa.eu/external_relations/asem/meetings/index_en.htm>

${ }^{30}$ Author interview April 2006 in Singapore.

${ }^{31}$ Author interview May 2006 in Warsaw.

${ }^{32}$ Hwee, "The Inter-Regional Dimension of EU-Asia Relations," p. 178.

33 Jürgen Rüland, "Interregionalism. An Unfinished Agenda", in Jürgen Rüland et al. (eds), Interregionalism and International Relations, London: Routledge, 2006, p. 300.

${ }_{34}$ European Commission, "EU trade relations with ASEAN," $<$ http://trade.ec.europa.eu/doclib/docs/2008/may/tradoc_138792.pdf>

${ }^{35}$ European Commission, "Evaluation of EC Co-operation with ASEAN - ref. 1262, Vol. 2," p. 22, $<$ http://ec.europa.eu/europeaid/how/evaluation/evaluation_reports/reports/2009/1262_vol2_en.pdf>

${ }^{36}$ Author interviews with ASEAN officials and national government officials from several member states in Jakarta and Kuala Lumpur (October 2008) and Hanoi (June 2010).

37 ASEM, "Beijing Declaration on Sustainable Development, 2008," $<$ http://www.asem7.cn/misc/2008-10/25/content_57456.htm>

${ }^{38}$ Ronald L. Jepperson et al., "Norms, Identity, and Culture in National Security", in Peter J. Katzenstein (ed.), The Culture of National Security: Norms and Identity in World Politics, New York: Columbia University Press, 1996, p. 54.

${ }^{39}$ Francesca Cancian, What are Norms?, Cambridge: Cambridge University Press, 1975, p. 6.

${ }^{40}$ Arturo Santa-Cruz, "International Development Assistance as an International Norm: The Japanese Experience," México y la Cuenca del Pacífico, Vol 11, No. 33, 2008, pp. 11-38.

${ }^{41}$ Nathalie Tocci, Profiling Normative Foreign Policy: The European Union and its Global Partners, CEPS Working Document No. 279, December 2007.

${ }^{42}$ François Duchêne, "The European Community and the Uncertainties of Interdependence," in Max Kohnstamm and Wolfgang Hager (eds.), A Nation Writ Large? Foreign Policy Problems before the European Community, London: Macmillan, 1973.

${ }^{43}$ Joseph S. Nye, Soft Power: The Means to Success in World Politics, New York: Public Affairs, 2004.

${ }^{44}$ ASEM, "Chairman's Statement of the Third Asia-Europe Meeting, Seoul, 20-21 October," $<$ http://www.aseminfoboard.org/content/documents/chairmans_statement_asem_3.pdf>

${ }^{45}$ Michael Reiterer, "ASEM-the Third Summit in Seoul 2000: A Roadmap to Consolidate the Partnership between Asia and Europe," European Foreign Affairs Review, Vol. 6, 2001, p. 17.

${ }^{46}$ Maria-Gabriela Manea, "Human Rights and the Interregional Dialogue between Asia and Europe: ASEAN-EU Relations and ASEM," The Pacific Review, Vol. 2, No. 1, 2008, p. 380.

${ }^{4747}$ Ibid., p. 392. 